\title{
Correction to: The mercury sphygmomanometer: soon a museum piece!
}

\author{
Hassan Al-Riyami • Sunil K. Nadar $\mathbb{D}$
}

Published online: 2 March 2021

(c) The Author(s), under exclusive licence to Springer Nature Limited 2021

Correction to: Journal of Human Hypertension https://doi.org/10.1038/s41371-020-00462-8

Unfortunately, reference number 11 has been printed wrong. Youssef $\mathrm{G}$ is missing from the list. It should be "Ghareeb S, Youssef G, Ghareeb HS, El-Mageed HA,
Mesalm MH, Talaat R, Eltawil A, et al. Results of the project of calibration of mercury sphygmomanometer blood pressure measuring devices in Egypt. J Hum Hypertens. 2020. (in press)"

The original article has been corrected. 